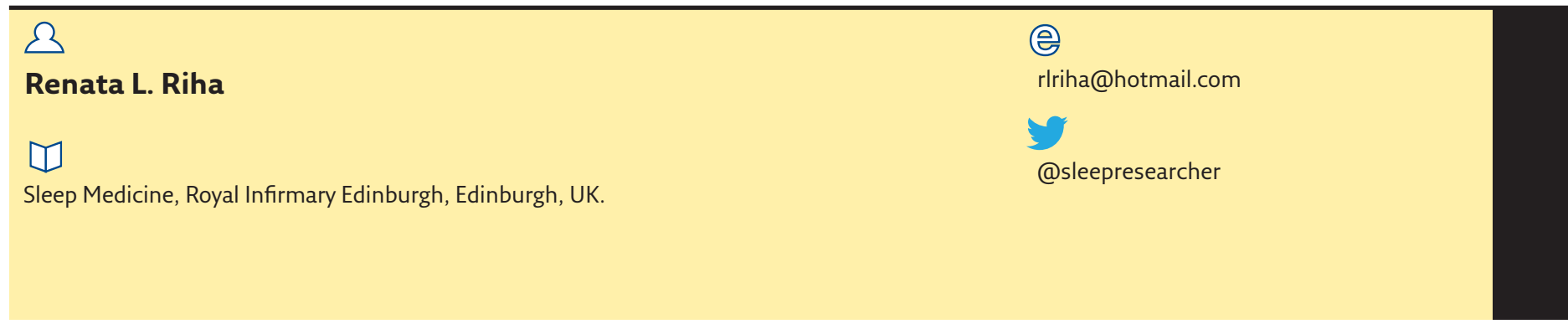

\title{
Breathe: palliative care in respiratory medicine
}

Several decades ago when I was still at medical school, the standard teaching on palliative care was delivered by a formidable anaesthetist who focused on the five stages of grief in the dying process as propounded by Elizabeth Kubler-Ross: denial, anger, bargaining, depression and acceptance [1].

No distinction was made between types of disease in the context of palliation and the focus was always on cancer. This is the model many of us have grown up with and accepted as a given in our daily practice, applying it in our care for patients and their families. However, once we ourselves start to experience grief and loss in our personal lives, the Kubler-Ross model becomes much more difficult to accept. For one, it is not based in very much evidence and ignores the complexity and interplay of emotions and reactions to disability and death which are not linear in nature. Mostly, there is no peaceful resolution. In addition, the model ignores the importance of resilience even in the face of no-win situations and a strong will to survive against the odds inherent to the human condition [2].

This issue of Breathe focuses on palliative care in respiratory medicine and from reading the editorials and the review articles you may appreciate that times have moved on and our approach to caring for those at the wrong end of life has evolved dramatically. However, we also need to consider another aspect of care which has been briefly touched on: the bereavement process of not only the individual who is facing death, but also those around him/her, including the caregivers. A number of institutions have introduced bereavement programmes, which involve both staff and family, and the hospice movement has introduced a holistic approach to caring for the individual and their loved ones [3, 4]. Our role as healthcare providers must not be overlooked, and care must be exercised to ensure that burnout does not afflict those in such an emotionally charged specialty as palliative care [5].

There are many excellent books and papers in the area of end-of-life care; Atul Gawande's Being Mortal comes highly recommended [6]. Numerous poets too have tackled these difficult subjects, possibly even more astutely reflecting universal human experiences of death, loss and grief. Edna St Vincent Millay, for instance, argues against acceptance of the finality of death in contrast to our long-accepted medical model in her poem Dirge without Music [7]:
"I am not resigned to the shutting away of loving hearts in the hard ground.
So it is, and so it will be, for so it has been, time out of mind:
Into the darkness they go, the wise and the lovely. Crowned
With lilies and with laurel they go; but I am not resigned."

My hope is that many of the contributions to this issue become part of a catalogue of recommended references in this area of medicine as they stimulate you to reflect on your own experiences and your own approaches in practice.

Thanks, as ever, to all contributors and the hardworking team at the ERS publications office and to our readers - happy holidays to you all!
Cite as: Riha RL. Breathe: palliative care in respiratory medicine. Breathe 2017; 13 267-268. 


\section{Conflict of interest:}

None declared.

\section{References}

1. Kubler-Ross, E. On death and dying. New York, The MacMillan Company, 1969.

2. Stroebe M, Schut H, Boerner K. Cautioning health-care professionals. Omega (Westport) 2017; 74: 455-473.

3. Morris SE, Block SD. Adding value to palliative care services: the development of an institutional bereavement program. J Palliat Med 2015; 18: 915-922.

4. Centeno C, Clark D, Lynch T, et al. Facts and indicators on palliative care development in 52 countries of the WHO
European region: results of an EAPC Task Force. Palliat Med 2007: 21: 463-471

5. Linzitto JP, Grance G. Health professionals' quality of life in relation to end of life care. Curr Opin Support Palliat Care 2017 in press [https://doi.org/10.1097/SPC.0000000000000307]. 6. Gawande, A. Being mortal: medicine and what matters in the end. New York, Metropolitan Books, Henry Holt and Company, 2014. 7. St. Vincent Millay E. Dirge Without Music. www. poetryfoundation.org/poems/52773/dirge-without-music 